\title{
INTERGENERATIONAL PERSISTENCE OF HEALTH IN THE U.S.: DO IMMIGRANTS GET HEALTHIER AS THEY ASSIMILATE?
}

\author{
Mevlude Akbulut-Yuksel \\ Adriana D. Kugler \\ Working Paper 21987 \\ http://www.nber.org/papers/w21987 \\ NATIONAL BUREAU OF ECONOMIC RESEARCH \\ 1050 Massachusetts Avenue \\ Cambridge, MA 02138 \\ February 2016
}

We are grateful to seminar participants at the University of Houston, IZA and at the Royal Economic Society Conference in Warwick. The views expressed herein are those of the authors and do not necessarily reflect the views of the National Bureau of Economic Research.

NBER working papers are circulated for discussion and comment purposes. They have not been peerreviewed or been subject to the review by the NBER Board of Directors that accompanies official NBER publications.

(C) 2016 by Mevlude Akbulut-Yuksel and Adriana D. Kugler. All rights reserved. Short sections of text, not to exceed two paragraphs, may be quoted without explicit permission provided that full credit, including $(\odot$ notice, is given to the source. 
Intergenerational Persistence of Health in the U.S.: Do Immigrants Get Healthier as they Assimilate? Mevlude Akbulut-Yuksel and Adriana D. Kugler

NBER Working Paper No. 21987

February 2016

JEL No. I12,I14,J61,J62

\begin{abstract}
It is well known that a substantial part of income and education is passed on from parents to children, generating substantial persistence in socio-economic status across generations. In this paper, we examine whether another form of human capital, health, is also largely transmitted from generation to generation, contributing to limited socio-economic mobility. Using data from the NLSY, we first present new evidence on intergenerational transmission of health outcomes in the U.S., including weight, height, the body mass index (BMI), asthma and depression for both natives and immigrants. We show that both native and immigrant children inherit a prominent fraction of their health status from their parents, and that, on average, immigrants experience higher persistence than natives in weight and BMI. We also find that mothers' education decreases children's weight and BMI for natives, while single motherhood increases weight and BMI for both native and immigrant children. Finally, we find that the longer immigrants remain in the U.S., the less intergenerational persistence there is and the more immigrants look like native children. Unfortunately, the more generations immigrant families remain in the U.S., the more children of immigrants resemble natives' higher weights, higher BMI and increased propensity to suffer from asthma.
\end{abstract}

\author{
Mevlude Akbulut-Yuksel \\ Department of Economics \\ Dalhousie University \\ PO Box 15000 \\ 6214 University Avenue \\ Halifax, Nova Scotia \\ B3H 4R2 CANADA \\ and IZA \\ mevlude@dal.ca \\ Adriana D. Kugler \\ Georgetown University \\ McCourt School of Public Policy \\ 37th and O Streets NW, Suite 311 \\ Washington, DC 20057 \\ and NBER \\ ak659@georgetown.edu
}




\section{Introduction}

Even in a society that is considered highly mobile like the United States, it is well established that socio-economic status is largely determined by parental income. Several studies have shown that the income of both natives and immigrants is highly correlated to the income of their parents (Solon, 1992; Zimmerman, 1992; Borjas, 1992), pointing to a high level of persistence in socio-economic status and limited opportunities for social mobility. These studies, however, have not decomposed the estimated intergenerational income correlations into causal components. Such decomposition would help to identify factors that promote or delay mobility and also identify possible policies to increase social mobility. A further decomposition would help to identify the extent to which the causal components reflect genetic or environmental influences addressing the nature versus nurture debate. Human capital theory suggests that education and health are key endowments affecting intergenerational transmission of economic status and earnings (Behrman et al, 1994).

While a substantial literature focuses on the intergenerational transmission of schooling, much less work has focused on the intergenerational transmission of health. However, a growing literature shows that aside from education, health status such as height (Persico et al., 2004; Case and Paxson, 2008), obesity (Cawley, 2004), and health conditions (Currie and Madrian, 1999) are also important determinants of earnings differentials. Health capital is an important component of an individual's stock of human capital affecting labor market outcomes (Mushkin, 1962; Grossman, 1972; Currie and Madrian, 1999). The literature on intergenerational transmission of socio-economic 
outcomes has so far focused almost exclusively on cognitive skills and investments in education. Just as importantly, intergenerational mobility in non-cognitive attributes, including individual's physical and mental health, may also provide important insights in understanding high persistence in economic status.

The objective of this paper is to examine the extent of intergenerational transmission in health outcomes including weight, height, the body mass index (BMI), asthma and depression. We investigate these intergenerational correlations separately for natives and immigrants from different generations. We address two questions about the intergenerational transmission of health status. First, we examine the extent of the intergenerational transmission of health for natives and immigrants and ask whether these intergenerational correlations differ between natives and immigrants. Second, we investigate whether those who have been in the U.S for various generations are more mobile compared to more recent immigrants. That is, do immigrants assimilate towards natives as they stay in the United States for more generations?

To answer these questions, we use a nationally representative data set, the National Longitudinal Survey of Youth, which follows mothers in 1979 through 2004 and their children in 1994 through 2004. This feature of the data set enables us to link mother and their children as well as sibling mothers. This is important because we can compare the health outcomes of children of sisters (i.e., cousins), thus controlling for grandparents' fixed effects and accounting for many prominent genetic and environmental attributes that are common in a family tree.

To preview our main results, we find that both native and immigrant children attain an important fraction of their health capital from their mother. We further show that 
mother's health outcomes contribute to generate persistence across generations both in terms of anthropometric measures: weight, height and BMI as well as specific conditions, such as asthma, and emotional health outcomes, such as depression. This remains true even when we introduce a rich set of controls for children's and mothers' characteristics and grandparents' fixed effects models. We also find that mother's education increases and single motherhood reduces children's health status independently. Finally, we find that the longer immigrants remain in the U.S. the more mobile they are in terms of health status and the less their health status is determined by their mothers. In particular, we find less persistence in weight, BMI and asthma for third generation than for second and first generation children. However, this also means that the longer immigrant families remain in the U.S., the more their children resemble native children in their propensity to be overweight and to experience asthma.

The remainder of the paper is organized as follows. Section 2 reviews the previous literature on intergenerational mobility. Section 3 describes the main empirical strategy and Section 4 describes the data. Section 5 presents the main results using Ordinary-LeastSquares for natives and immigrants as well as the OLS results with averages. Section 6 concludes.

\section{Literature Review}

Research on inter-generational transmission of health status was first put forward by Sir Galton's well-known pioneering study, in which he examined the relationship between children's heights and their parents in 1886. Galton showed that the height of 
children is some fraction of the parent's height and that height is not fully passed on, but rather converges towards the mean (i.e., "regress[es] towards mediocrity").

While a handful of studies examine the degree of intergenerational mobility in earnings and economic status across countries and over time (Solon, 1992; Zimmerman, 1992; Corak, 2004; Ferrie, 2005; Yuksel, 2007), few studies have attempted to investigate the intergenerational transmission of health outcomes. The intuition that individuals' health along with their education endowments may provide important insights in understanding the mobility of earnings was first argued by Ahlburg (1998). He proposes that further investigation of mechanisms underlying intergenerational mobility in earnings will help us to identify the extent to which the causal components reflect genetic or environmental influences, that is address the nature versus nurture debate. Eriksson, Bratsberg and Raaum (2007) provide similar analyses using the Danish Youth Cohort Study. They find significant correlations in health problems across generations. They also show that children from low-income families are more likely to experience health problems in adulthood, even when they control for parental health problems.

Several studies address the intergenerational transmission in birth weight. Emanuel et al. (1992) find a positive relation between infant and parents' birth weight using 1958 British Birth Cohort Study. Similarly, Collins et al. (2002) use Illinois vital statistics records to analyze correlations in birth weight among US-born and foreign-born white and black women. They document a general increase in average birth weights across generations among native-born women. However, among immigrant women the pattern was reversed for black immigrant women who have babies of higher birth weight than their 
native-born daughters. Currie and Moretti (2007) revisit the same question using individual birth records from California and show substantial intergenerational correlation in health.

This study also relates to the literature looking at the association between mother's socioeconomic status and children's health. These studies have shown that mother's education is strongly associated with infants' birth weight both in U.S. and in developing countries (Strauss and Thomas, 1995, for developing countries; Currie and Moretti, 2003, for the U.S.). They find that more educated mothers are less likely to have low or very low birth weight babies, and their babies are less likely to die within their first year of life. Other studies also find that these effects persist well into adulthood. For example, Case, Fertig and Paxson (2005) find that mother's education predicts self-reported health at age 42. In line with this research, we also investigate the impact of mother's SES on children's health outcomes.

In addition, an extensive literature has clearly established that individual's health is an important component of labor market success. For instance, the effects of obesity on labor market outcomes for the U.S. and Europe have been assessed in a large number of studies. One of the most robust findings is that obese women tend to earn less than their non-obese counterparts and there are differences by ethnicity and race in the U.S., while results are not as robust for Europe (Cawley, 2004, for the U.S.; Garcia and QuintanaDomeque, 2006, for Europe). On the other hand, Black et al. (2007) use data from Norway and find that lower birth babies have worse outcomes both in the short-run in terms of oneyear mortality rate and in the longer-run in terms of educational attainment and earnings. Taken together, these studies suggest that both overweight and low birth weight individuals tend to earn less. 
Other studies also examine the relation between height and earnings and find that a person's height is strongly correlated with his or her income. Judge and Cable (2004), Persico et al. (2004) and Case and Paxson (2008) find similar results and report that for both men and women an additional inch of height is associated with a one to two percent increase in earnings in the U.S. Taken together, these studies suggest that labor market rewards height and penalize obesity and low birth weight.

Along these findings, we believe that examining to what extent health endowments are transmitted across generations will improve our understanding of the persistence in earnings and income. We are not aware of any study that investigates the intergenerational transmission in health outcomes including height, weight, BMI, asthma and depression. This study, thus, contributes to this literature by considering new channels of intergenerational transmission of socio-economic status and by looking at the differential patterns for natives and immigrants.

\section{Estimation Framework}

In this study, we examine the similarity in health outcomes between mothers and children using the following regression,

$$
\mathrm{H}_{1 i}=\rho \mathrm{H}_{0 i}+\beta \mathrm{X}_{1 i}+\varepsilon_{1 i}
$$

where $\mathrm{H}_{1 \mathrm{i}}$ is child health outcomes including weight, height, BMI, asthma and depression; $\mathrm{H}_{0 \mathrm{i}}$ is the health outcomes of mother; $\mathrm{X}_{1 \mathrm{i}}$ includes all other characteristics of the mother's generation that affect children's health outcomes as well as the child characteristics; and $\varepsilon_{1 \mathrm{i}}$ is a random shock. This equation should be regarded as a reduced-form equation, where

$\rho$ being determined by multiple factors containing genetic and behavior attributes 
transmitted from mothers to children. In this setting, $\mathrm{H}_{0 \mathrm{i}}$ controls for all of the factors that affected the mother's health outcomes, while $\mathrm{X}_{1 \mathrm{i}}$ will include additional characteristics of the mother that did not affect her own health outcomes and grandmother fixed effects to control for genetic or broader unobservable environmental factors.

The coefficient $\rho$ measures the degree of persistence or immobility in the society and is the fraction of the mother's health status that her child inherits. Estimates of $\rho$ close to unity imply high persistence and limited mobility whereas values of $\rho$ close to zero suggest low persistence and almost complete intergenerational mobility in health outcomes. Most empirical studies in the intergenerational mobility of earnings and education between father-son pairs find $\rho$ to lie between zero and one, while some studies investigating the mobility of economic status between father-daughter and motherdaughter pairs have found negative estimates of $\rho .^{2}$ Thus, we can expect to find coefficients between zero and one.

We begin with models estimating the direct impact of mother's health outcomes on children's health outcomes, turning afterwards to models that incorporate controls for the child's race, sex and age to control for potential age differentials. Ignoring variables such as mother's total household income, mother's years of education, mother's marital status, and residence in an urban or rural area and unemployment rate in the region of residence when the mother was first interviewed that might be correlated with children's health may yield to upwardly biased estimates of $\rho$. Therefore, to address the potential omitted

\footnotetext{
${ }^{2}$ Presumably, any real number could be obtained from the estimation of equation (1); a negative value of $\rho$ would refer to a situation where mothers are high in their generations' distribution of health, while their children tend to be low in their own generations' distribution.
} 
variables problem, we introduce these additional controls to equation (1). One may expect the persistence coefficient to fall as we include more controls to the model.

In addition, we also re-estimate equation (1) including grandparents' fixed effects. Grandparents' fixed effect enables us to assess the effect of mother's health outcomes on children's health outcomes, exploiting variation between children of sisters that have at least one and generally two common parents. Including grandparents' fixed effects allows us to control for genetic traits, mother's background characteristics as well as the family environment when the mother was growing up. The difference that may arise between models with and without grandparents' fixed effects can be attributed to all other remaining genetic differences and contemporaneous factors that differentially affect children's health outcomes.

A potentially important limitation in estimating (1) is that health variables are selfreported, which raises the issue of measurement error. In addition, mother's health outcomes may be subject to transitory shocks such as:

$$
H_{0 i}=H_{0 i}^{*}+\mu_{0 i}
$$

where $\mathrm{H}_{0 \mathrm{i}}$ * is the permanent health outcome and $\mu_{0 \mathrm{i}}$ captures transitory fluctuations around long-run status due to transitory shocks and random measurement error. Then, applying least squares to equation (1) using $\mathrm{H}_{0 \mathrm{i}}$ instead of $\mathrm{H}_{0 \mathrm{i}}$ * will lead to a downward bias in estimates due to classical measurement error in mother's health outcomes. In particular, the probability limit of the estimated slope coefficient $\rho$ is

$$
\operatorname{plim} \hat{\rho}=\left[\sigma_{H}^{2} /\left(\sigma_{H}^{2}+\sigma_{\mu_{0}}^{2}\right)\right]<\rho
$$

The magnitude of this bias depends on the ratio of signal to total variance, 
$\left[\sigma_{H}^{2} /\left(\sigma_{H}^{2}+\sigma_{\mu_{0}}^{2}\right)\right]$ where $\sigma_{H}^{2}$ is the variance of mother's permanent health status, and $\sigma_{\mu 0}{ }^{2}$ is the variance of transitory shocks to the permanent health status. Following the literature on intergenerational transmission of economic status (Solon, 1992; Zimmerman, 1992), we attempt to reduce the bias arising due to classical measurement error by averaging mother's health outcomes over multiples years. Applying least square estimation and assuming the errors are uncorrelated over time would yield an estimate of $\rho$ with probability limit

$$
\operatorname{plim} \widehat{\rho_{a v g}}=\rho\left[\sigma_{H}^{2} /\left(\sigma_{H}^{2}+\sigma_{\mu_{0}}^{2} / T\right)\right]
$$

where T stands for the number of years. Presumably, the bias will decrease as we average mother's health status over more years.

\section{Data Description}

The empirical analysis relies on two data sets to analyze the degree of intergenerational transmission of health for both natives and immigrants in the U.S. First, we use the National Longitudinal Survey of Youth 1979 (NLSY79), which has information on parents' health outcomes as well as parents' household characteristics. All young individuals in the sample were between fourteen and twenty-two years of age as of December 1978. In accordance with the NLSY79 sample design, all eligible individuals aged 14 to 21 residing in a surveyed household at the end of 1978 were selected as respondents. As a result, the 11,406 civilian respondents interviewed in 1979 originated from 7,490 unique households; 2,862 households included more than one NLSY79 respondent, consisting of 5,914 siblings.

For the children's health outcomes, we utilize Children of NLSY79, Young Adult

File. The children's sample consists of all children born to female NLSY79 respondents. This sample is nationally representative of the children of women who were born from 
1957 to 1964 and who are living in the United States in 1978. Starting in 1994, NLSY79 children who were 15 years old or older by the end of the interview year were interviewed separately as young adults. We focus on these young adults in our analysis.

The NLSY79 and the Children of NLSY79 Young Adult File have information on both children's and parents' self-reported weight, height, BMI, and prevalence of asthma and depression. Both data sets also provide information about a rich set of individual and household characteristics such as race, sex, age, immigration status, marital status, total household income, and whether the mother and child live in an urban area and the unemployment rate in the region of residence. Essential to the purpose of this paper, we are able to link mothers' health outcomes as well as their demographic data to their children's health outcomes and demographic data at the same point in their life cycle, which is not possible in most of the available data.

Our analysis is primarily conducted using 3,921 mother-children pairs for natives and 914 for immigrants. We include all NLSY79 female respondents that have a child in Children of the NLSY79 Young Adult File and who have non-missing information on health outcomes between 1981 and 1994. Similarly, for the children's generation, we include all children in 2004, who have information about their own health outcomes.

Table 1 presents descriptive statistics for the young adult sample separately for natives and immigrants from different generations. We define a first generation immigrant as an immigrant who was born outside the United States herself and whose parents and grandfather were also born outside the U.S. The second-generation immigrants are those who were born in the U.S and either their mother or father was born outside the U.S. NLSY79 also includes information about the birthplace of the grandfather which enables 
us to identify the third generation immigrants. Using this information, we classify third generation immigrants as those whose grandfathers were born outside the United States and both themselves and their parents born in the U.S. In this table, we present descriptive statistics of for immigrants of first, second and third generation mothers.

From Table 1, it can be observed that natives are heavier, taller, have higher BMI and are more likely to report being depressed compared to immigrants from all generations. Note, however, that column (6) in Table 1 shows that the children of third generation immigrants look similar to natives in terms of health outcomes. Focusing on children of third generation mothers, we see that these children are heavier, taller, have higher BMI and are more likely to have asthma than children of immigrant mothers from more recent generations. The increase in the resemblance between natives and immigrants who have been in the United States for various generations points to the assimilation of immigrants towards native norms in terms of health outcomes.

Table 2 reports summary statistics of mothers separately for natives and immigrants. Similar to children, native mothers are also heavier, taller, have higher BMI and are more likely to have asthma relative to immigrant mothers. In addition, native mothers have more years of schooling and higher total household income compared to first and second generation immigrants. On the other hand, third generation immigrant mothers look very similar to natives in terms of both health outcomes and household characteristics such as years of education, total household income and marital status in 1979. The fact that third generation immigrants have more years of education as well as higher total household income suggests that immigrants also assimilate towards natives in terms of income and education as they stay in the U.S. for various generations. 
Comparing age of children and mothers in Tables 1 and 2 shows that the mean age for children is 19 years of age, while the mean age for mothers' generation is 21 years of age. This pairing represents the earliest observational date for mothers and latest observational date for children. Mothers and children are captured at around the same stage of their lifecycle; thus, helping us to avoid any potential issues that may arise due to age differentials across generations.

\section{Results on Inter-generational Transmission of Health Status}

This section presents estimates of intergenerational mobility in health outcomes using measures of health including weight, height, BMI, asthma and depression.

\section{A. Intergenerational Persistence in Weight, Height and BMI}

All OLS estimations involving weight, height and BMI are conducted using 1981 information for the mothers' generation and 2004 information for the children's generation. We choose these years to eliminate age-related differences in health outcomes. As indicated above, the mean age for mothers and children is approximately 20 in 1981 for mothers and in 2004 for children.

\section{A.1. Inter-generational Transmission of Weight}

We begin the empirical analysis with an examination of the association between mother's weight and child's weight. Results are reported in Panel A of Table 3, separately for children of native-born and immigrant mothers. Columns (1) and (5) show estimations from models without controls for children of natives and immigrants, respectively. These estimates can be interpreted as $50 \%$ of the mother's weight is transmitted to her children for natives, while immigrant children attain $70 \%$ of their weight from their mother. 
Although, we observe a lot of persistence in terms of weight across generations for both natives and immigrants, comparison of persistence coefficient between natives and immigrants suggest that persistence is stronger for immigrants. In columns (2) and (6), we control for children's characteristics by including children's sex, race and, in particular, by including both the child's and mother's age to account for the fact that health outcomes may be sensitive to a person's age. To illustrate, the coefficient estimate in column (2) drops by 7.6 percent for natives and by 18.1 percent for immigrants mainly due to the gender and racial differentials in weight outcomes. In addition, once we control for children's characteristics, the persistence coefficient is no longer significantly different between natives and immigrants. This finding suggests that the differences in the racial composition of natives and immigrants might lead to a substantial difference in intergenerational transmission of weight.

The extent of intergenerational transmission of weight may differ between individuals belonging to different SES groups. In order to consider such differences, we estimate models including additional controls for mother's background characteristics such as total household income, years of education, and marital status, and the unemployment rate in the area of residence and whether the mother lived in an urban area in 1979. Columns (3) and (7) contain corresponding estimates for persistence of weight across generations introducing controls for mother's background characteristics. Although the estimated coefficients on mother's weight are somewhat reduced after we account for mother's background characteristics, we still observe a lot of persistence in weight across generations both natives and immigrants. 
Just as importantly, from column (3), it appears that mother's years of education has a large impact on the weight of native mothers' children. More specifically, every additional year of mother's education is associated with 2.41 pounds decrease in child's weight in 2004 for natives. On the other hand, column (7) provides evidence suggesting that mother's education decreases an immigrant child's weight as well, though small numbers of observations makes it hard to detect this effect. Interestingly, immigrant children of married mothers tend to be 15 pounds thinner compared to children of single mothers indicating that the detrimental impact of single motherhood is stronger for immigrant than native children. Moreover, in contrast to previous studies examining the extent of the intergenerational transmission of birth weight (Currie and Moretti, 2003; Currie and Moretti, 2007), we find that the mother's other background variables, whether being in low income quartile and unemployment rate in the region of residence, have no effect on children's health outcomes for both natives and immigrants.

Finally, columns (4) and (8) show models including grandparents' fixed effects. This specification takes advantage of variation among children of siblings as an only source of variation, and therefore controls for many permanent unobserved factors that might vary across families. Despite the fact that standard errors increase substantially, the point estimates on mother's weight virtually remains unchanged for natives in these models. Thus, even after controlling for genetic factors, the effects of mother's health outcomes remain large.

\section{A.2. Intergenerational Transmission of Height}

Height of population reflects both its genetic endowment and its long-run nutritional intake and health status (Fogel, 1994). This observation suggests that a child's 
height is determined by combination of his/her genetic endowments as well as the environment the child grew up in and the SES of his/her family. To explore the extent to which a mother's height is transmitted to her children, we estimate intergenerational transmission models for height as well. The persistence coefficients of height are displayed in Panel B of Table 3 separately for native and immigrant children. The coefficient estimates on mother's height reveal a lot of persistence in terms of height across generation as well, though the persistence in height is slightly less compared to persistence in weight across different specifications. From Column (1) and (5) of Panel B, it appears that native children attain $40 \%$ of their height from their mothers, whereas the corresponding coefficient for children of immigrants is $47 \%$. Although children of immigrants are somewhat more likely to inherit their mothers' height, the persistence coefficient is not appreciably different between native and immigrant children. These persistence coefficients on individual's height are similar or higher than the persistence coefficient of education, which was estimated as 0.46 for the U.S. (Hertz et al. 2007). Given the wellestablished causal link between height and personal success, our findings underscore the importance of parents' health capital for individuals' health endowments as well as in understanding the strong persistence in economic status across generations in the United States.

Columns (2), (3), (6) and (7) of Panel B show the effects by sequentially introducing the variables discussed above. Including more controls for both child's characteristics as well as mother's background lead the persistence coefficient to fall as expected in almost all specifications. Additionally, in contrast to child's weight, it seems that mother's socio-economic status in general does not have any impact on height of native 
children, while immigrant children from lower-income families attain lower height as adults. The two remaining columns in Panel B display the estimates obtained using grandparents' fixed effects. From these columns, we clearly note that a great fraction of the mother's height is transmitted to child, in particular, for natives even when we control for genetic traits and mother's background characteristics.

\section{A.3. Inter-generational Transmission of BMI}

We also consider the magnitude of the intergenerational correlation in the body mass index (BMI), defined as weight measured in kilograms divided by height measured in meters. BMI has a particular importance, as it reflects both height and weight of the individual and is known as a standard measure of fatness and obesity in epidemiology and medicine (Cawley, 2004). Panel C of Table 3 contains the ordinary-least-squares estimates of the persistence coefficients for BMI. The results clearly indicate that mother's BMI is transmitted to her child, suggesting that there is a great deal of intergenerational transmission across generations even when we incorporate more precise measures of health. From Panel C, the baseline specification indicates that children of native mothers attain 45 percent of their mothers' BMI, while children of immigrant mothers inherit 58 percent of their mothers' BMI.

Importantly, the results controlling for mother's characteristics continue to show greater persistence for immigrants than natives. In addition, models accounting for mother's background characteristics document that the human capital of mothers is important in determining children's BMI for both natives and immigrants. In addition, mother's marital status also seems to matter for child's BMI along with mother's education, in particular for children of immigrants. Just as importantly, models including 
grandparents' fixed effects yield point estimates of the persistence coefficients that remain virtually unchanged for natives, though standard error are somewhat higher.

\section{A.4. OLS Results with Averages}

Table 4 directs attention toward the possibility of measurement error in the mother's health outcomes. Averaging mother's health status should improve the ratio of signal to total variance, thus reducing the extent of error-in-variables bias. Results are presented using children's health outcomes in 2004 and two and three year's averages for mothers' health status. The estimates corresponding to a three-year averages of mother's health status are 0.455 for weight, 0.424 for height, and 0.412 for BMI. Overall, the persistence coefficient for natives increase, as we average over more years for all health outcomes. Therefore, comparison of estimates using single year measures for mother's health outcomes with those averaging mother's health status over two and three years clearly suggests that measurement error is indeed a problem for natives. Therefore, accounting for error-in-variables will increase the persistence of health status across generations. On the other hand, for immigrants we find increased persistence merely for height when we use two- and three-year averages of mother's health status. In addition, in line with our previous findings, we find that the persistence for natives is similar to those of immigrants even when introducing three-year averages of mother's health status.

\section{B. Intergenerational Persistence of Asthma and Depression}

We only observe whether mothers experienced asthma in 2004 and whether they experienced depression in 1992 and 1994. Although we are not able to capture motherchild pairs exactly in the same point in their lifecycle, we still believe that it is worthwhile 
to conduct analyses using asthma and depression to see to what extent children's specific health conditions are influenced by the attributes of the mother.

\section{B.1. Intergenerational Transmission of Asthma}

Studies of intergenerational transmission of health have been generally focused on special diseases as cancer and Alzheimer's to understand the association between genes and specific diseases (Ahlburg, 1998). In this paper, we instead analyze the intergenerational transmission of asthma to assess to what extent this highly prevalent disease is being transmitted over generations. Panel A of Table 5 reports estimation results for asthma conditions. The point estimates on a mother having asthma indicate that the intergenerational correlation in asthma is approximately $17 \%$ for children of natives and $22 \%$ for children of immigrants, although these persistence coefficients are not significantly different from each other.

\section{B.2. Inter-generational Transmission of Depression Status}

Having shown that there is indeed a lot of persistence in physical health measures including weight, height, BMI and asthma, we will now describe the results for a psychological health outcome, depression. We define depression as an indicator variable that equals to one if the respondent has experienced depression. Panel B of Table 5 displays the estimation results for depression. Native children of depressed mothers are more likely to report they experienced depression as well, suggesting intergenerational transmission of mental health across generations. Surprisingly, we do not observe the same pattern for immigrants. The point estimates of persistence coefficient range from $7.6 \%$ to $8.6 \%$ across different specifications suggesting that the children of depressed native mother are on average $8 \%$ more likely to be depressed latter on in their life compared to children of non- 
depressed mothers. We also find that children of less educated mothers are more susceptible to depression, while other household characteristics seem to be unrelated to depression. By contrast, there is no evidence of any intergenerational transmission of depression among immigrants.

\section{Intergenerational Persistence in Health for Immigrants of Different Generations}

Table 6 and 7 shows results of intergenerational persistence for children of first, second and third generation immigrant mothers. The results show that persistence coefficients in weight and BMI are smaller for third generation than second and first generation immigrants. ${ }^{3}$ Thus, as immigrants remain longer in the U.S., they resemble less their mother's weight and BMI and these measures depend more on other factors. In fact, third generation children show a tendency to assimilate towards native children. As shown, in Table 1, third generation immigrant children look more similar to native children. The tendency towards higher weight and BMI are, however, not necessarily positive since these move immigrants towards being overweight.

\section{Conclusion}

In this study, we use National Longitudinal Survey of Youth to investigate the extent of intergenerational correlation in health separately for natives and immigrants.

We provide new evidence on intergenerational transmission of health status across generations. We find that both native and immigrant children inherit anthropometric health measures such as weight, height and BMI from their mothers. We also find that children's

\footnotetext{
${ }^{3}$ Interestingly, the persistence coefficients for height in Panel B of Table 6 do not show this same patterns. Similarly, the results for asthma and depression in Table 7 do not show a clear change in the persistence coefficients.
} 
health conditions such as asthma and mental health conditions such as depression are, to a great extent, also inherited from their mothers. This high correlation persists even when a rich set of controls, including mother's background characteristics and grandparents' fixed effects are introduced into the models. We also show that mother's education is negatively associated with children's weight and the body mass index. In addition, we find that single motherhood increases weight for both native and immigrant children.

Finally, we find evidence of immigrant assimilation in health as immigrants remain for more generations in the U.S. The intergenerational correlation coefficient decreases for third generation compared to second and first generation immigrant children. This means that the longer immigrant families remain in the U.S., the less likely immigrant children's health outcomes are to look like their mothers'. Indeed, higher generation immigrant children are more likely to resemble native children in terms of higher weight and BMI. 


\section{References}

Ahlburg Dennis. 1998. "Intergenerational Transmission of Health" American Economic Review Papers and Proceedings, 88 (2): 265-270.

Behrman, Jere, Mark Rosenzweig, and Paul Taubman. 1994. "Endowments and the Allocation of Schooling in the Family and in the Marriage Market: The Twins Experiment." Journal of Political Economy, 6 (102): 1131-74.

Black, Sandra, Paul Devereux, and Kjell G. Salvanes. 2007. "From the Cradle to the Labor Market? The Effect of Birth Weight on Adult Outcomes." Quarterly Journal of Economics, 122 (1): 409-439.

Borjas, George J. 1992. "Ethnic Capital and Intergenerational Mobility." Quarterly Journal of Economics, 107 (1): 123-150.

Case, Anne and Christina Paxson. 2008. "Stature and Status: Height, Ability, and Labor Market Outcomes.” Journal of Political Economy, 116 (3): 499-532.

Case, Anne, Angela Fertig and Christina Paxson. 2005. "The Lasting Impact of Childhood Health and Circumstance." Journal of Health Economics, 24 (2): 365-389.

Cawley, John. 2004. "Body Weight and Women's Labor Market Outcomes.” Journal of Human Resources, 39(2): 451-474.

Collins, James W, Shou-Yien Wu, and Richard David. 2002. "Differing Intergenerational Birth Weights Among the Descendants of U.S.-born and Foreign-born Whites and African Americans in Illinois," American Journal of Epidemiology, 155 (3): 210-216

Corak, Miles. 2004. "Generational Income Mobility in North America and Europe," Cambridge: Cambridge University Press.

Currie, J. and Brigitte Madrian. 1999. "Health, Health Insurance and the Labor Market." in O. Ashenfelter and D. Card, eds., Handbook in Labor Economics, Volume 3, pp. 33093415. Amsterdam: Elsevier.

Currie Janet and Enrico Moretti. 2007. "Biology as Destiny? Short and Long-Run Determinants of Intergenerational Transmission of Birth Weight." Journal of Labor Economics, 25 (2): 231-264.

Currie, Janet and Enrico Moretti. 2003. "Mother's Education and the Intergenerational Transmission of Human Capital: Evidence from College Openings." Quarterly Journal of Economics, 118 (4): 1495-1532. 
Eriksson, Tor, Bratsberg, Bernt and Raaum, Oddbjarn. 2005. "Earnings Persistence across Generations: Transmission through Health?" Oslo University, Department of Economics, Unpublished Manuscript.

Ferrie, Joseph P. 2005. "The End of American Exceptionalism? Mobility in the United States since 1850." Journal of Economic Perspectives, 19 (3): 199-215.

Fogel, Robert. 1992. "Second Thoughts on the European Escape from Hunger: Famines, Chronic Malnutrition and Mortality Rates," in S. R. Osmani, ed., Nutrition and Poverty, pp. 243-86. Oxford: Clarendon.

Galton, Francis. 1886. "Regression towards Mediocrity in Hereditary Stature." Journal of the Anthropological Institute of Great Britain and Ireland, 15: 246-263.

Garcia, Jaume and Climent Quintana-Domeque. 2005. "Obesity, Wages and Employment in Europe.” EconWPA Working Paper.

Grossman, Michael. 1972. "On the Concept of Health Capital and the Demand for Health." Journal of Political Economy, 80 (2): 223-255.

Hertz Tom, Tamara Jayasundera, Patrizio Piraino, Sibel Selcuk, Nicole Smith, and Alina Verashchagina. 2007. "The Inheritance of Educational Inequality: International Comparisons and Fifty-year Trends." The B.E. Journal of Economic Analysis and Policy, 7 (2): 1935-1682.

Judge, Timothy A., and Daniel M. Cable. 2004. "The Effect of Physical Height on Workplace Success and Income: Preliminary Test of a Theoretical Model." Journal of Applied Psychology, 89 (1): 428-441.

Kuhn, Peter and Catherine Weinberger. 2005. "Leadership Skills and Wages." Journal of Labor Economics, 23 (3): 395-436.

Mushkin, Selma J. "Health as an Investment.” Journal of Political Economy, 70(S5): 129129.

Persico Nicola, Andrew Postlewaite and Dan Silverman. 2004. "The Effect of Adolescent Experience on Labor Market Outcomes: The Case of Height." Journal of Political Economy, 112(5): 1019-1053.

Strauss, John and Duncan Thomas. 1995. "Human Resources: Empirical Modeling of Household and Family Decision." in J. Behrman and T.N. Srinivasan, eds., Handbook of Development Economics, Vol. 3, Amsterdam: Elsevier Science.

Solon, Gary R. 1992. "Intergenerational Income Mobility in the United States." American Economic Review, 82 (3): 393-408. 
Yuksel, Mutlu. 2007. "Intergenerational Mobility of Immigrants in Germany: Moving with Natives or Stuck in their Neighborhoods?" IZA Working Paper No. 4677.

Zimmerman, David J. 1992. "Regression toward Mediocrity in Economic Stature." American Economic Review, 82 (3): 409-429. 


\begin{tabular}{|c|c|c|c|c|c|c|}
\hline & \multirow{2}{*}{$\begin{array}{l}\text { All } \\
(1) \\
\end{array}$} & \multirow{2}{*}{$\begin{array}{c}\text { Natives } \\
(2) \\
\end{array}$} & \multicolumn{4}{|c|}{ Immigrants } \\
\hline & & & $\begin{array}{l}\text { All } \\
(3)\end{array}$ & $\begin{array}{c}\text { 1st Gen. } \\
(4)\end{array}$ & $\begin{array}{c}\text { 2nd Gen. } \\
(5)\end{array}$ & $\begin{array}{c}\text { 3rd Gen. } \\
(6)\end{array}$ \\
\hline Weight (in pounds) & $\begin{array}{c}158.388 \\
(40.570)\end{array}$ & $\begin{array}{c}159.708 \\
(40.570)\end{array}$ & $\begin{array}{l}152.695 \\
(37.732)\end{array}$ & $\begin{array}{l}150.742 \\
(34.203)\end{array}$ & $\begin{array}{l}151.321 \\
(35.543)\end{array}$ & $\begin{array}{l}156.286 \\
(43.110)\end{array}$ \\
\hline Height (in inches) & $\begin{array}{l}67.048 \\
(4.125)\end{array}$ & $\begin{array}{l}67.155 \\
(4.143)\end{array}$ & $\begin{array}{l}66.589 \\
(4.017)\end{array}$ & $\begin{array}{l}66.386 \\
(3.998)\end{array}$ & $\begin{array}{l}66.281 \\
(3.864)\end{array}$ & $\begin{array}{l}67.102 \\
(4.121)\end{array}$ \\
\hline BMI & $\begin{array}{l}24.739 \\
(5.557)\end{array}$ & $\begin{array}{l}24.872 \\
(5.659)\end{array}$ & $\begin{array}{l}24.165 \\
(5.058)\end{array}$ & $\begin{array}{l}24.065 \\
(4.608)\end{array}$ & $\begin{array}{l}24.184 \\
(4.958)\end{array}$ & $\begin{array}{l}24.273 \\
(5.644)\end{array}$ \\
\hline Depression & $\begin{array}{c}0.288 \\
(0.453)\end{array}$ & $\begin{array}{c}0.295 \\
(0.456)\end{array}$ & $\begin{array}{c}0.260 \\
(0.439)\end{array}$ & $\begin{array}{c}0.259 \\
(0.438)\end{array}$ & $\begin{array}{c}0.271 \\
(0.445)\end{array}$ & $\begin{array}{c}0.252 \\
(0.434)\end{array}$ \\
\hline Asthma in 2004 & $\begin{array}{c}0.176 \\
(0.381)\end{array}$ & $\begin{array}{c}0.175 \\
(0.380)\end{array}$ & $\begin{array}{c}0.180 \\
(0.385)\end{array}$ & $\begin{array}{c}0.150 \\
(0.357)\end{array}$ & $\begin{array}{c}0.213 \\
(0.410)\end{array}$ & $\begin{array}{c}0.188 \\
(0.392)\end{array}$ \\
\hline Age & $\begin{array}{l}18.648 \\
(3.490)\end{array}$ & $\begin{array}{l}18.711 \\
(3.523)\end{array}$ & $\begin{array}{l}18.376 \\
(3.330)\end{array}$ & $\begin{array}{l}18.443 \\
(3.292)\end{array}$ & $\begin{array}{l}18.362 \\
(3.358)\end{array}$ & $\begin{array}{l}18.303 \\
(3.356)\end{array}$ \\
\hline Female & $\begin{array}{c}0.488 \\
(0.500)\end{array}$ & $\begin{array}{c}0.487 \\
(0.500)\end{array}$ & $\begin{array}{c}0.493 \\
(0.500)\end{array}$ & $\begin{array}{l}0.477 \\
(0.500)\end{array}$ & $\begin{array}{c}0.487 \\
(0.500)\end{array}$ & $\begin{array}{l}0.517 \\
(0.500)\end{array}$ \\
\hline White & $\begin{array}{c}0.456 \\
(0.498)\end{array}$ & $\begin{array}{c}0.438 \\
(0.496)\end{array}$ & $\begin{array}{c}0.533 \\
(0.499)\end{array}$ & $\begin{array}{l}0.418 \\
(0.493)\end{array}$ & $\begin{array}{l}0.573 \\
(0.495)\end{array}$ & $\begin{array}{l}0.648 \\
(0.478)\end{array}$ \\
\hline Black & $\begin{array}{c}0.389 \\
(0.488)\end{array}$ & $\begin{array}{c}0.461 \\
(0.498)\end{array}$ & $\begin{array}{l}0.082 \\
(0.275)\end{array}$ & $\begin{array}{l}0.074 \\
(0.262)\end{array}$ & $\begin{array}{l}0.090 \\
(0.287)\end{array}$ & $\begin{array}{l}0.086 \\
(0.280)\end{array}$ \\
\hline Hispanic & $\begin{array}{c}0.224 \\
(0.417)\end{array}$ & $\begin{array}{c}0.132 \\
(0.339)\end{array}$ & $\begin{array}{c}0.615 \\
(0.487)\end{array}$ & $\begin{array}{l}0.799 \\
(0.401)\end{array}$ & $\begin{array}{c}0.630 \\
(0.483)\end{array}$ & $\begin{array}{l}0.360 \\
(0.480)\end{array}$ \\
\hline American Indian & $\begin{array}{c}0.014 \\
(0.116)\end{array}$ & $\begin{array}{c}0.014 \\
(0.119)\end{array}$ & $\begin{array}{l}0.010 \\
(0.102)\end{array}$ & $\begin{array}{l}0.006 \\
(0.078)\end{array}$ & $\begin{array}{l}0.006 \\
(0.077)\end{array}$ & $\begin{array}{l}0.020 \\
(0.140)\end{array}$ \\
\hline Asian $\backslash$ Pasific Islander & $\begin{array}{c}0.004 \\
(0.062)\end{array}$ & $\begin{array}{c}0.002 \\
(0.049)\end{array}$ & $\begin{array}{c}0.010 \\
(0.097)\end{array}$ & $\begin{array}{l}0.018 \\
(0.133)\end{array}$ & $\begin{array}{l}0.003 \\
(0.057)\end{array}$ & $\begin{array}{l}0.004 \\
(0.061)\end{array}$ \\
\hline Other race & $\begin{array}{c}0.091 \\
(0.287)\end{array}$ & $\begin{array}{c}0.056 \\
(0.231)\end{array}$ & $\begin{array}{l}0.238 \\
(0.426)\end{array}$ & $\begin{array}{l}0.307 \\
(0.462)\end{array}$ & $\begin{array}{l}0.215 \\
(0.411)\end{array}$ & $\begin{array}{l}0.168 \\
(0.374)\end{array}$ \\
\hline $\mathrm{N} \max$. & 19,165 & 15,541 & 3,624 & 1,484 & 998 & 1,142 \\
\hline
\end{tabular}

Notes: First, second and third generations refer to mothers' generation. 


\begin{tabular}{|c|c|c|c|c|c|c|}
\hline & \multirow{2}{*}{$\begin{array}{l}\text { All } \\
(1) \\
\end{array}$} & \multirow{2}{*}{$\begin{array}{c}\text { Natives } \\
(2) \\
\end{array}$} & \multicolumn{4}{|c|}{ Immigrants } \\
\hline & & & $\begin{array}{l}\text { All } \\
(3)\end{array}$ & $\begin{array}{c}\text { 1st Gen. } \\
(4)\end{array}$ & $\begin{array}{c}\text { 2nd Gen. } \\
(5)\end{array}$ & $\begin{array}{c}\text { 3rd Gen. } \\
(6)\end{array}$ \\
\hline Weight (in pounds) & $\begin{array}{l}133.706 \\
(25.754)\end{array}$ & $\begin{array}{l}134.500 \\
(26.006)\end{array}$ & $\begin{array}{l}130.639 \\
(24.519)\end{array}$ & $\begin{array}{l}129.447 \\
(23.529)\end{array}$ & $\begin{array}{l}129.491 \\
(23.447)\end{array}$ & $\begin{array}{l}132.873 \\
(26.228)\end{array}$ \\
\hline Height (in inches) & $\begin{array}{l}64.047 \\
(2.724)\end{array}$ & $\begin{array}{l}64.210 \\
(2.702)\end{array}$ & $\begin{array}{l}63.413 \\
(2.717)\end{array}$ & $\begin{array}{l}62.915 \\
(2.721)\end{array}$ & $\begin{array}{l}63.508 \\
(2.855)\end{array}$ & $\begin{array}{l}63.845 \\
(2.502)\end{array}$ \\
\hline BMI & $\begin{array}{l}22.957 \\
(4.228)\end{array}$ & $\begin{array}{l}22.983 \\
(4.278)\end{array}$ & $\begin{array}{l}22.854 \\
(4.027)\end{array}$ & $\begin{array}{l}22.945 \\
(3.922)\end{array}$ & $\begin{array}{l}22.642 \\
(3.968)\end{array}$ & $\begin{array}{l}22.944 \\
(4.174)\end{array}$ \\
\hline Depression & $\begin{array}{c}0.382 \\
(0.486)\end{array}$ & $\begin{array}{c}0.387 \\
(0.487)\end{array}$ & $\begin{array}{c}0.362 \\
(0.481)\end{array}$ & $\begin{array}{c}0.408 \\
(0.492)\end{array}$ & $\begin{array}{c}0.387 \\
(0.487)\end{array}$ & $\begin{array}{c}0.285 \\
(0.452)\end{array}$ \\
\hline Asthma in 2004 & $\begin{array}{c}0.134 \\
(0.341)\end{array}$ & $\begin{array}{c}0.136 \\
(0.343)\end{array}$ & $\begin{array}{c}0.126 \\
(0.332)\end{array}$ & $\begin{array}{c}0.092 \\
(0.289)\end{array}$ & $\begin{array}{c}0.166 \\
(0.372)\end{array}$ & $\begin{array}{c}0.128 \\
(0.334)\end{array}$ \\
\hline Age & $\begin{array}{l}21.257 \\
(3.198)\end{array}$ & $\begin{array}{l}21.222 \\
(3.200)\end{array}$ & $\begin{array}{l}21.393 \\
(3.187)\end{array}$ & $\begin{array}{l}21.609 \\
(3.189)\end{array}$ & $\begin{array}{l}20.912 \\
(3.183)\end{array}$ & $\begin{array}{l}21.581 \\
(3.143)\end{array}$ \\
\hline Non-Black, Non-Hispanic & $\begin{array}{l}0.531 \\
(0.499)\end{array}$ & $\begin{array}{l}0.563 \\
(0.496)\end{array}$ & $\begin{array}{l}0.410 \\
(0.492)\end{array}$ & $\begin{array}{l}0.211 \\
(0.408)\end{array}$ & $\begin{array}{l}0.350 \\
(0.477)\end{array}$ & $\begin{array}{l}0.680 \\
(0.466)\end{array}$ \\
\hline Black & $\begin{array}{l}0.277 \\
(0.447)\end{array}$ & $\begin{array}{l}0.332 \\
(0.471)\end{array}$ & $\begin{array}{l}0.065 \\
(0.246)\end{array}$ & $\begin{array}{l}0.095 \\
(0.293)\end{array}$ & $\begin{array}{l}0.062 \\
(0.241)\end{array}$ & $\begin{array}{l}0.035 \\
(0.184)\end{array}$ \\
\hline Hispanic & $\begin{array}{l}0.192 \\
(0.394)\end{array}$ & $\begin{array}{l}0.105 \\
(0.307)\end{array}$ & $\begin{array}{l}0.525 \\
(0.499)\end{array}$ & $\begin{array}{l}0.694 \\
(0.461)\end{array}$ & $\begin{array}{l}0.588 \\
(0.492)\end{array}$ & $\begin{array}{l}0.285 \\
(0.451)\end{array}$ \\
\hline $\begin{array}{l}\text { Years of Education } \\
\text { in } 1979\end{array}$ & $\begin{array}{l}10.331 \\
(2.039)\end{array}$ & $\begin{array}{l}10.381 \\
(1.934)\end{array}$ & $\begin{array}{l}10.135 \\
(2.393)\end{array}$ & $\begin{array}{l}9.339 \\
(2.797)\end{array}$ & $\begin{array}{l}10.210 \\
(1.947)\end{array}$ & $\begin{array}{l}10.944 \\
(1.935)\end{array}$ \\
\hline $\begin{array}{l}\text { Total Household Income } \\
\text { in } 1979\end{array}$ & $\begin{array}{c}16.268 .09 \\
(12675.76)\end{array}$ & $\begin{array}{c}16.210 .36 \\
(12931.35)\end{array}$ & $\begin{array}{c}16.485 .22 \\
(11662.42)\end{array}$ & $\begin{array}{c}14.551 .93 \\
(10331.92)\end{array}$ & $\begin{array}{c}15.007 .83 \\
(11410.39)\end{array}$ & $\begin{array}{r}19.920 .88 \\
(12387.57)\end{array}$ \\
\hline Married in 1979 & $\begin{array}{l}0.183 \\
(0.386)\end{array}$ & $\begin{array}{l}0.180 \\
(0.384)\end{array}$ & $\begin{array}{l}0.194 \\
(0.396)\end{array}$ & $\begin{array}{l}0.253 \\
(0.435)\end{array}$ & $\begin{array}{l}0.174 \\
(0.379)\end{array}$ & $\begin{array}{l}0.147 \\
(0.354)\end{array}$ \\
\hline Urban at age 14 & $\begin{array}{l}0.793 \\
(0.405)\end{array}$ & $\begin{array}{l}0.776 \\
(0.417)\end{array}$ & $\begin{array}{l}0.858 \\
(0.349)\end{array}$ & $\begin{array}{l}0.870 \\
(0.336)\end{array}$ & $\begin{array}{l}0.837 \\
(0.369)\end{array}$ & $\begin{array}{l}0.862 \\
(0.345)\end{array}$ \\
\hline $\begin{array}{l}\text { Unemp. Rate in Region } \\
\text { in } 1979\end{array}$ & $\begin{array}{l}6.151 \\
(2.235)\end{array}$ & $\begin{array}{l}6.102 \\
(2.117)\end{array}$ & $\begin{array}{l}6.335 \\
(2.627)\end{array}$ & $\begin{array}{c}6.315 \\
(2.548)\end{array}$ & $\begin{array}{c}6.329 \\
(2.731)\end{array}$ & $\begin{array}{c}6.364 \\
(2.620)\end{array}$ \\
\hline$\overline{\mathrm{N} \text { max. }}$ & 991,424 & $\overline{72,464}$ & 1818,960 & 7,008 & 5,576 & 6,376 \\
\hline
\end{tabular}


Table 3. Intergenerational Transmission of Health Outcomes

\begin{tabular}{|c|c|c|c|c|c|c|c|c|}
\hline & \multicolumn{4}{|c|}{ Children of Native-Born } & \multicolumn{4}{|c|}{ Children of Immigrants } \\
\hline & $(1)$ & $(2)$ & $(3)$ & $(4)$ & $(5)$ & $(6)$ & $(7)$ & $(8)$ \\
\hline \multicolumn{9}{|c|}{ Panel A: Child's Weight } \\
\hline Mother's Weight & $\begin{array}{l}0.499 * * * \\
(0.040)\end{array}$ & $\begin{array}{c}0.461 * * * \\
(0.040)\end{array}$ & $\begin{array}{c}0.429 * * * \\
(0.056)\end{array}$ & $\begin{array}{l}0.370^{*} \\
(0.197)\end{array}$ & $\begin{array}{c}0.706 * * * \\
(0.090)\end{array}$ & $\begin{array}{c}0.578^{* * * *} \\
(0.087)\end{array}$ & $\begin{array}{c}0.488^{* * * *} \\
(0.089)\end{array}$ & $\begin{array}{l}-0.176 \\
(0.594)\end{array}$ \\
\hline Low Income Quantile & & & $\begin{array}{l}2.068 \\
(2.697)\end{array}$ & $\begin{array}{c}9.945 \\
(16.426)\end{array}$ & & & $\begin{array}{l}-3.076 \\
(4.001)\end{array}$ & $\begin{array}{c}-3.984 \\
(21.969)\end{array}$ \\
\hline $\begin{array}{l}\text { Mother's Education } \\
\text { in } 1979\end{array}$ & & & $\begin{array}{c}-2.409^{* *} \\
(1.022)\end{array}$ & $\begin{array}{l}4.058 \\
(3.331)\end{array}$ & & & $\begin{array}{l}-1.308 \\
(1.110)\end{array}$ & $\begin{array}{l}-2.128 \\
(8.153)\end{array}$ \\
\hline Married in 1979 & & & $\begin{array}{c}-2.705 \\
(10.540)\end{array}$ & $\begin{array}{c}-50.733 * * * \\
(17.407)\end{array}$ & & & $\begin{array}{l}-15.145^{* *} \\
(5.927)\end{array}$ & $\begin{array}{r}61.461 * * \\
(30.576)\end{array}$ \\
\hline $\begin{array}{l}\text { Unemp. Rate in Region } \\
\text { in } 1979\end{array}$ & & & $\begin{array}{c}0.709 \\
(0.472)\end{array}$ & $\begin{array}{c}6.016 \\
(4.175)\end{array}$ & & & $\begin{array}{c}0.454 \\
(0.686)\end{array}$ & \\
\hline $\mathrm{R}^{2}$ & 0.077 & 0.283 & 0.244 & 0.744 & 0.153 & 0.402 & 0.385 & 0.829 \\
\hline $\mathrm{N}$ & 3921 & 3508 & 2068 & 2068 & 914 & 850 & 488 & 488 \\
\hline \multicolumn{9}{|c|}{ Panel B: Child's Height } \\
\hline Mother's Height & $\begin{array}{c}0.404 * * * \\
(0.031)\end{array}$ & $\begin{array}{c}0.421 * * * \\
(0.024)\end{array}$ & $\begin{array}{c}0.393 * * * \\
(0.029)\end{array}$ & $\begin{array}{c}0.332 * * * \\
(0.097)\end{array}$ & $\begin{array}{c}0.471 * * * \\
(0.067)\end{array}$ & $\begin{array}{c}0.466 * * * \\
(0.060)\end{array}$ & $\begin{array}{c}0.387 * * * \\
(0.074)\end{array}$ & $\begin{array}{c}0.015 \\
(0.202)\end{array}$ \\
\hline Low Income Quantile & & & $\begin{array}{c}0.093 \\
(0.179)\end{array}$ & $\begin{array}{l}-1.466 \\
(1.626)\end{array}$ & & & $\begin{array}{l}-0.020 \\
(0.398)\end{array}$ & $\begin{array}{c}-4.422 * * \\
(2.208)\end{array}$ \\
\hline $\begin{array}{l}\text { Mother's Education } \\
\text { in } 1979\end{array}$ & & & $\begin{array}{c}0.083 \\
(0.088)\end{array}$ & $\begin{array}{l}-0.007 \\
(0.259)\end{array}$ & & & $\begin{array}{c}0.083 \\
(0.124)\end{array}$ & $\begin{array}{c}1.523 \\
(1.038)\end{array}$ \\
\hline Married in 1979 & & & $\begin{array}{c}0.463 \\
(0.601)\end{array}$ & $\begin{array}{l}-0.103 \\
(1.317)\end{array}$ & & & $\begin{array}{l}-0.163 \\
(0.566)\end{array}$ & $\begin{array}{c}9.750^{* * * *} \\
(3.389)\end{array}$ \\
\hline $\begin{array}{l}\text { Unemp. Rate in Region } \\
\text { in } 1979\end{array}$ & & & $\begin{array}{l}-0.006 \\
(0.037)\end{array}$ & $\begin{array}{c}0.133 \\
(0.312)\end{array}$ & & & $\begin{array}{l}-0.013 \\
(0.066)\end{array}$ & \\
\hline $\mathrm{R}^{2}$ & 0.062 & 0.56 & 0.547 & 0.825 & 0.09 & 0.556 & 0.541 & 0.867 \\
\hline $\mathrm{N}$ & 3,955 & 3,539 & 2,087 & 2,087 & 916 & 852 & 488 & 488 \\
\hline \multicolumn{9}{|c|}{ Panel C: Child's BMI } \\
\hline Mother's BMI & $\begin{array}{c}0.449 * * * \\
(0.032)\end{array}$ & $\begin{array}{c}0.392 * * * \\
(0.035)\end{array}$ & $\begin{array}{c}0.383 * * * \\
(0.051)\end{array}$ & $\begin{array}{c}0.422^{* *} \\
(0.175)\end{array}$ & $\begin{array}{c}0.578^{* * * *} \\
(0.072)\end{array}$ & $\begin{array}{c}0.465^{* * *} \\
(0.064)\end{array}$ & $\begin{array}{c}0.538^{* * * *} \\
(0.081)\end{array}$ & $\begin{array}{l}-0.303 \\
(0.515)\end{array}$ \\
\hline Low Income Quantile & & & $\begin{array}{c}0.315 \\
(0.401)\end{array}$ & $\begin{array}{c}3.023 \\
(2.683)\end{array}$ & & & $\begin{array}{l}-0.386 \\
(0.654)\end{array}$ & $\begin{array}{c}4.476 \\
(2.888)\end{array}$ \\
\hline $\begin{array}{l}\text { Mother's Education } \\
\text { in } 1979\end{array}$ & & & $\begin{array}{c}-0.440 * * * \\
(0.155)\end{array}$ & $\begin{array}{c}0.538 \\
(0.468)\end{array}$ & & & $\begin{array}{l}-0.280 \\
(0.183)\end{array}$ & $\begin{array}{l}-2.801 * \\
(1.471)\end{array}$ \\
\hline Married in 1979 & & & $\begin{array}{l}-0.906 \\
(1.573)\end{array}$ & $\begin{array}{l}-7.724 * * * \\
(2.088)\end{array}$ & & & $\begin{array}{c}-2.437 * * * \\
(0.939)\end{array}$ & $\begin{array}{c}7.311 \\
(5.029)\end{array}$ \\
\hline $\begin{array}{l}\text { Unemp. Rate in Region } \\
\text { in } 1979\end{array}$ & & & $\begin{array}{l}0.116^{*} \\
(0.066)\end{array}$ & $\begin{array}{c}0.761 \\
(0.591)\end{array}$ & & & $\begin{array}{c}0.056 \\
(0.102)\end{array}$ & \\
\hline $\mathrm{R}^{2}$ & 0.092 & 0.164 & 0.158 & 0.718 & 0.157 & 0.227 & 0.255 & 0.793 \\
\hline $\mathrm{N}$ & 3,899 & 3,487 & 2,052 & 2,052 & 897 & 835 & 479 & 479 \\
\hline Child's Age, Sex and Race & & Yes & Yes & Yes & & Yes & Yes & Yes \\
\hline Household Characteristics & & & Yes & Yes & & & Yes & Yes \\
\hline Grandmother Fixed Effect & & & & Yes & & & & Yes \\
\hline
\end{tabular}




\begin{tabular}{|c|c|c|c|c|c|c|}
\hline & \multicolumn{3}{|c|}{ Children of Native-Born } & \multicolumn{3}{|c|}{ Children of Immigrants } \\
\hline & $\frac{\text { 1-Year }}{(1)}$ & $\frac{\text { 2-Years }}{(2)}$ & $\frac{\text { 3-Years }}{(3)}$ & $\frac{\text { 1-Year }}{(4)}$ & $\frac{\text { 2-Years }}{(5)}$ & $\frac{\text { 3-Years }}{(6)}$ \\
\hline \multicolumn{7}{|c|}{ Panel A: Child's Weight } \\
\hline Mother's Weight & $\begin{array}{r}0.429 * * * \\
(0.056)\end{array}$ & $\begin{array}{r}0.442 * * * \\
(0.060)\end{array}$ & $\begin{array}{r}0.455^{* * *} \\
(0.057)\end{array}$ & $\begin{array}{r}0.488 * * * \\
(0.089)\end{array}$ & $\begin{array}{r}0.469^{* * * *} \\
(0.102)\end{array}$ & $\begin{array}{r}0.402 * * * \\
(0.103)\end{array}$ \\
\hline Low Income Quartile & $\begin{array}{r}2.068 \\
(2.697)\end{array}$ & $\begin{array}{r}1.786 \\
(2.705)\end{array}$ & $\begin{array}{r}2.273 \\
(2.735)\end{array}$ & $\begin{array}{l}-3.076 \\
(4.001)\end{array}$ & $\begin{array}{r}-3.377 \\
(4.260)\end{array}$ & $\begin{array}{r}-4.032 \\
(4.378)\end{array}$ \\
\hline $\begin{array}{l}\text { Mother's Education } \\
\text { in } 1979\end{array}$ & $\begin{array}{r}-2.409 * * \\
(1.022)\end{array}$ & $\begin{array}{r}-2.320^{* *} \\
(1.002)\end{array}$ & $\begin{array}{r}-2.243 * * \\
(1.004)\end{array}$ & $\begin{array}{r}-1.308 \\
(1.110)\end{array}$ & $\begin{array}{l}-1.166 \\
(1.129)\end{array}$ & $\begin{array}{l}-1.258 \\
(1.192)\end{array}$ \\
\hline Married in 1979 & $\begin{array}{r}-2.705 \\
(10.540)\end{array}$ & $\begin{array}{r}-3.132 \\
(10.690)\end{array}$ & $\begin{array}{r}-2.927 \\
(10.672)\end{array}$ & $\begin{array}{r}-15.145^{* *} * \\
(5.927)\end{array}$ & $\begin{array}{r}-13.362 * * \\
(6.784)\end{array}$ & $\begin{array}{r}-12.469 * \\
(7.001)\end{array}$ \\
\hline $\begin{array}{l}\text { Unemp. Rate in Region } \\
\text { in } 1979\end{array}$ & $\begin{array}{r}0.709 \\
(0.472)\end{array}$ & $\begin{array}{r}0.666 \\
(0.473)\end{array}$ & $\begin{array}{r}0.736 \\
(0.474)\end{array}$ & $\begin{array}{r}0.454 \\
(0.686)\end{array}$ & $\begin{array}{r}0.348 \\
(0.716)\end{array}$ & $\begin{array}{r}0.508 \\
(0.726)\end{array}$ \\
\hline $\mathrm{R}^{2}$ & $\begin{array}{l}0.244 \\
2.068\end{array}$ & $\begin{array}{l}0.247 \\
2.052\end{array}$ & $\begin{array}{l}0.255 \\
2.007\end{array}$ & $\begin{array}{r}0.385 \\
488\end{array}$ & $\begin{array}{r}0.377 \\
473\end{array}$ & $\begin{array}{r}0.371 \\
462\end{array}$ \\
\hline \multicolumn{7}{|c|}{ Panel B: Child's Height } \\
\hline Mother's Height & $\begin{array}{r}0.393^{* * *} \\
(0.029)\end{array}$ & $\begin{array}{r}0.417 \text { *** } \\
(0.029)\end{array}$ & $\begin{array}{r}0.424 * * * \\
(0.029)\end{array}$ & $\begin{array}{r}0.387 * * * \\
(0.074)\end{array}$ & $\begin{array}{r}0.430^{* * * *} \\
(0.081)\end{array}$ & $\begin{array}{r}0.446^{* * * *} \\
(0.083)\end{array}$ \\
\hline Low Income Quartile & $\begin{array}{r}0.093 \\
(0.179)\end{array}$ & $\begin{array}{r}0.089 \\
(0.179)\end{array}$ & $\begin{array}{r}0.127 \\
(0.179)\end{array}$ & $\begin{array}{r}-0.020 \\
(0.398)\end{array}$ & $\begin{array}{r}-0.015 \\
(0.406)\end{array}$ & $\begin{array}{r}-0.026 \\
(0.404)\end{array}$ \\
\hline $\begin{array}{l}\text { Mother's Education } \\
\text { in } 1979\end{array}$ & $\begin{array}{r}0.083 \\
(0.088)\end{array}$ & $\begin{array}{r}0.077 \\
(0.090)\end{array}$ & $\begin{array}{r}0.075 \\
(0.091)\end{array}$ & $\begin{array}{r}0.083 \\
(0.124)\end{array}$ & $\begin{array}{r}0.088 \\
(0.125)\end{array}$ & $\begin{array}{r}0.101 \\
(0.128)\end{array}$ \\
\hline Married in 1979 & $\begin{array}{r}0.463 \\
(0.601)\end{array}$ & $\begin{array}{r}0.423 \\
(0.601)\end{array}$ & $\begin{array}{r}0.486 \\
(0.607)\end{array}$ & $\begin{array}{r}-0.163 \\
(0.566)\end{array}$ & $\begin{array}{r}-0.020 \\
(0.567)\end{array}$ & $\begin{array}{r}0.072 \\
(0.571)\end{array}$ \\
\hline $\begin{array}{l}\text { Unemp. Rate in Region } \\
\text { in } 1979\end{array}$ & $\begin{array}{r}-0.006 \\
(0.037)\end{array}$ & $\begin{array}{r}-0.005 \\
(0.037)\end{array}$ & $\begin{array}{r}-0.004 \\
(0.037)\end{array}$ & $\begin{array}{r}-0.013 \\
(0.066)\end{array}$ & $\begin{array}{r}-0.021 \\
(0.068)\end{array}$ & $\begin{array}{r}-0.019 \\
(0.069)\end{array}$ \\
\hline $\mathrm{R}^{2}$ & 0.547 & 0.551 & 0.551 & 0.541 & 0.546 & 0.550 \\
\hline $\mathrm{N}$ & 2,087 & 2,074 & 2,041 & 488 & 474 & 467 \\
\hline \multicolumn{7}{|c|}{ Panel C: Child's BMI } \\
\hline Mother's BMI & $\begin{array}{r}0.383 * * * \\
(0.051)\end{array}$ & $\begin{array}{r}0.408 * * * \\
(0.054)\end{array}$ & $\begin{array}{r}0.412 * * * \\
(0.052)\end{array}$ & $\begin{array}{r}0.538 * * * \\
(0.081)\end{array}$ & $\begin{array}{r}0.535^{* * * *} \\
(0.081)\end{array}$ & $\begin{array}{r}0.452 * * * \\
(0.090)\end{array}$ \\
\hline Low Income Quartile & $\begin{array}{r}0.315 \\
(0.401)\end{array}$ & $\begin{array}{r}0.312 \\
(0.403)\end{array}$ & $\begin{array}{r}0.358 \\
(0.407)\end{array}$ & $\begin{array}{r}-0.386 \\
(0.654)\end{array}$ & $\begin{array}{r}-0.312 \\
(0.701)\end{array}$ & $\begin{array}{r}-0.418 \\
(0.726)\end{array}$ \\
\hline $\begin{array}{l}\text { Mother's Education } \\
\text { in } 1979\end{array}$ & $\begin{array}{r}-0.440 * * * \\
(0.155)\end{array}$ & $\begin{array}{r}-0.422 * * * \\
(0.153)\end{array}$ & $\begin{array}{r}-0.410 * * * \\
(0.154)\end{array}$ & $\begin{array}{r}-0.280 \\
(0.183)\end{array}$ & $\begin{array}{r}-0.273 \\
(0.187)\end{array}$ & $\begin{array}{r}-0.292 \\
(0.216)\end{array}$ \\
\hline Married in 1979 & $\begin{array}{r}-0.906 \\
(1.573)\end{array}$ & $\begin{array}{r}-0.932 \\
(1.597)\end{array}$ & $\begin{array}{r}-0.965 \\
(1.583)\end{array}$ & $\begin{array}{r}-2.437 * * * \\
(0.939)\end{array}$ & $\begin{array}{r}-2.064 * * \\
(1.014)\end{array}$ & $\begin{array}{r}-1.755^{*} \\
(1.055)\end{array}$ \\
\hline $\begin{array}{l}\text { Unemp. Rate in Region } \\
\text { in } 1979\end{array}$ & $\begin{array}{c}0.116^{*} \\
(0.066)\end{array}$ & $\begin{array}{c}0.109^{*} \\
(0.066)\end{array}$ & $\begin{array}{c}0.119 * \\
(0.067)\end{array}$ & $\begin{array}{r}0.056 \\
(0.102)\end{array}$ & $\begin{array}{r}0.020 \\
(0.107)\end{array}$ & $\begin{array}{r}0.048 \\
(0.111)\end{array}$ \\
\hline $\mathrm{R}^{2}$ & 0.158 & 0.161 & 0.169 & 0.255 & 0.244 & 0.225 \\
\hline $\mathrm{N}$ & 2,052 & 2,033 & 1,987 & 479 & 465 & 452 \\
\hline
\end{tabular}

Notes: Standard error are reported in parenthesis. Standard errors are clustered at the family level. Asterisks denote significance levels $(*=.10, * *=.05, * * *=.01)$. Other controls include child's sex, race, and age, mother's race and whether household lives in an urban area. Each regression is weighted using the 2004 Young Adult Weights. 


\section{Children of Native-Born}

Children of Immigrants

(1)

(2)

\section{Panel A: Asthma}

Mother has Asthma (0.029)

$(0.031)$

Low Income Quantile

Mother's Education

in 1979

Married in 1979

Unemp. Rate in Region

in 1979

$\mathrm{R}^{2}$

$\mathrm{N}$

Low Income Quartile

Mother's Education

in 1979

Married in 1979

Unemp. Rate in Region

in 1979

$\mathrm{R}^{2}$

$\mathrm{N}$

Child's Age, Sex and Race

Household Characteristics

Grandmother Fixed Effects

(0.045)

(0.085)

$\begin{array}{ll}0.024 & 0.033 \\ 3,785 & 3,395\end{array}$

0.036

$$
\text { (0.018) }
$$

(0.019)

(0.025)

(0.029)
Mother is Depressed

$0.173 * * * \quad 0.008$

(0.137)

$0.220 * * *$

$0.216^{* * * *}$

$0.255^{* * *}$

0.447

$(0.055) \quad(0.058) \quad(0.086)$

(0.701)

$\begin{array}{cc}0.002 & 0.500 \\ (0.026) & (0.527)\end{array}$

(0.026) (0.527)

$\begin{array}{ll}-0.004 \quad 0.002 \\ (0.011) & (0.034)\end{array}$

$(0.011) \quad(0.034)$

$0.021 \quad-0.033$

$(0.157)$

$\begin{array}{ll}-0.004 & -0.026\end{array}$

$(0.005) \quad(0.041)$

0.067

(0.064)

$-0.124$

$(0.261)$

$-0.003$

0.173

(0.014)

(0.114)

0.043

0.216

(0.094)

(0.302)

0.002

(0.009)

0.627

0.039

924

0.086

858

0.116

497

0.739

497

\section{Panel B: Depression}

$0.081 * * * \quad 0.076 * * * \quad 0.086 * * * \quad 0.118$

(0.102)

0.011

0.015

(0.035)

$(0.035)$

0.003

0.022

$(0.050)$

$(0.152)$

$\begin{array}{ll}-0.019 & -0.241 \\ (0.029) & (0.373)\end{array}$

$(0.373)$

$-0.018^{*} \quad-0.006$

(0.011) (0.043)

$-0.074 \quad-0.489$

(0.066) (0.333)

$-0.035$

(0.048)

0.259

$(0.328)$

$-0.019 \quad 0.078$

(0.017) (0.092)

$-0.090$

0.654

(0.082)

$(0.407)$

0.004

$\begin{array}{cc}0.001 & 0.027 \\ (0.005) & (0.035)\end{array}$

(0.008)

Notes : Standard error are reported in parenthesis. Standard errors are clustered at the family level. Asterisks denote significance levels $(*=.10, * *=.05, * * *=.01)$. Household characteristics include: mother's race, household income, mother's marital status, whether household lived in urban area and unemployment rate in current residence for the first year in which the mother was interviewed. In Panel A, each column is from a separate regression using 2004 for parents and young adults. In Panel B, data from 1992 is used for parents and from 2004 for young adults. Each regression is weighted using 2004 Young Adult Weights. 
Table 6. Intergenerational Transmission of Health across Immigrant Generations

\begin{tabular}{|c|c|c|c|c|}
\hline & $\frac{\text { All }}{(1)}$ & $\frac{\text { First }}{(2)}$ & $\frac{\text { Second }}{(3)}$ & $\frac{\text { Third }}{(4)}$ \\
\hline \multicolumn{5}{|c|}{ Panel A: Child's Weight } \\
\hline Mother's Weight & $\begin{array}{r}0.536^{* * * *} \\
(0.087)\end{array}$ & $\begin{array}{r}0.559 * * * \\
(0.125)\end{array}$ & $\begin{array}{r}0.465 * * * \\
(0.114)\end{array}$ & $\begin{array}{r}0.404 * * * \\
(0.101)\end{array}$ \\
\hline $\mathrm{R}^{2}$ & 0.392 & 0.391 & 0.338 & 0.427 \\
\hline $\mathrm{N}$ & 806 & 298 & 233 & 275 \\
\hline \multicolumn{5}{|c|}{ Panel B: Child's Height } \\
\hline Mother's Height & $\begin{array}{r}0.514 * * * \\
(0.064)\end{array}$ & $\begin{array}{r}0.457 * * * \\
(0.080)\end{array}$ & $\begin{array}{r}0.268 * * \\
(0.112)\end{array}$ & $\begin{array}{r}0.658 * * * \\
(0.097)\end{array}$ \\
\hline $\mathrm{R}^{2}$ & 0.559 & 0.630 & 0.559 & 0.607 \\
\hline $\mathrm{N}$ & 806 & 291 & 235 & 280 \\
\hline \multicolumn{5}{|c|}{ Panel C: Child's BMI } \\
\hline Mother's BMI & $\begin{array}{r}0.420 * * * \\
(0.062)\end{array}$ & $\begin{array}{r}0.509 * * * \\
(0.144)\end{array}$ & $\begin{array}{r}0.492 * * * \\
(0.096)\end{array}$ & $\begin{array}{r}0.319 * * * \\
\quad(0.070)\end{array}$ \\
\hline $\mathrm{R}^{2}$ & 0.213 & 0.215 & 0.23 & 0.291 \\
\hline $\mathrm{N}$ & 785 & 281 & 230 & 274 \\
\hline
\end{tabular}

Notes: Standard errors are reported in parenthesis. Standard errors are clustered at the family level. Asterisks denote significance levels $(*=.10, * *=.05, * * *=.01)$. Other controls include child's sex, age, race and mother's age. Each regression is is weighted using the 2004 Young Adult Weights. 
Table 7. Intergenerational Transmission of Health across Immigrant Generations

\begin{tabular}{|c|c|c|c|c|}
\hline & All & First & Second & Third \\
\hline & (1) & $(2)$ & $(3)$ & (4) \\
\hline & \multicolumn{4}{|c|}{ Panel A: Asthma } \\
\hline \multirow[t]{2}{*}{ Mother has Asthma } & $0.216 * * *$ & 0.122 & $0.305 * * *$ & 0.129 \\
\hline & $(0.058)$ & (0.119) & $(0.068)$ & $(0.084)$ \\
\hline $\mathrm{R}^{2}$ & 0.086 & 0.093 & 0.218 & 0.177 \\
\hline $\mathrm{N}$ & 858 & 339 & 235 & 284 \\
\hline
\end{tabular}

\section{Panel B: Depression}

Mother is Depressed

$\begin{array}{rrrr}0.039 & -0.007 & 0.006 & 0.069 \\ (0.042) & (0.072) & (0.080) & (0.078)\end{array}$

\begin{tabular}{lrrrr}
$\mathrm{R}^{2}$ & 0.085 & 0.183 & 0.224 & 0.095 \\
$\mathrm{~N}$ & 869 & 348 & 240 & 281 \\
\hline \hline
\end{tabular}

Notes: Standard errors are reported in parenthesis. Standard errors are clustered at the family level. Asterisks denote significance levels $(*=.10, * *=.05, * * *=.01)$. Other controls include child's sex, age, race and mother's age. Each column is weighted using the 2004 Young Adult Weights. 